\title{
Sovereignty over Land and Sea in the Arctic Area
}

\author{
Tullio Scovazzi*
}

\begin{abstract}
The paper reviews the claims over land and waters in the Arctic area. While almost all the disputes over land have today been settled, several questions relating to law of the sea are still pending. They regard straight baselines, navigation in ice-covered areas, transit through international straits, the outer limit of the continental shelf beyond 200 n.m. and delimitation of the exclusive economic zone between opposite or adjacent States.

Keywords: straight baselines, navigation in ice-covered areas, transit passage in international straits, external limit of the continental shelf, exclusive economic zone
\end{abstract}

\section{La soberanía sobre tierra y mar en el área ártica}

\section{RESUMEN}

El artículo examina los reclamos sobre el suelo y las aguas en el Ártico.

Mientras que casi todas las disputas sobre el suelo han sido resueltas al día de hoy, aún quedan pendientes muchas cuestiones relativas al derecho del mar. Ellas están referidas a las líneas de base rectas, la navegación en las zonas cubiertas de hielo, el paso en tránsito en estrechos internacionales, el límite externo de la plataforma continental más allá de las 200 millas náuticas, y la delimitación de la zona económica exclusiva entre Estados adyacentes u opuestos.

Palabras clave: Líneas de base rectas, navegación en zonas cubiertas de hielo, paso en tránsito en los estrechos internacionales, límite externo de la plataforma continental, zona económica exclusiva.

\footnotetext{
* Professor of International Law, University of Milano-Bicocca, Milan, Italy. tullio.scovazzi@unimib.it
} 


\section{Introduction}

This article aims at briefly reviewing a number of questions relating to the international regime of the Arctic area. Most of them regard the law of the sea and include several important issues, such as straight baselines (Art. 7 of the United Nations Convention on the Law of the Sea, adopted in Montego Bay in 1982; UNCLOS), navigation in ice-covered waters (Art. 234), transit through straits (Arts. from 34 to 44), the outer limit of the continental shelf beyond 200 n.m. (Art. 76), delimitation of exclusive economic zones (Arts. 74 and 83$)^{1}$. This makes a quite complex picture from the legal point of view.

\section{Questions of Sovereignty over Land}

The major issues of land sovereignty in the Arctic region have been settled in the first half of the twentieth century ${ }^{2}$. The treaty concerning the Archipelago of Spitzbergen (Paris, 1920) granted to Norway the sovereignty over the Spitzbergen archipelago, called also Svalbard 3 . On 5 April 1933 the Permanent Court of International Justice decided the dispute between Denmark and Norway on the legal status of Eastern Greenland, recognizing the sovereignty of Denmark over it. The Court took into account «the Arctic and inaccessible character of the uncolonized parts of the country» (PCJI, 1933: 50) and the legislation on hunting and fishing adopted by Denmark. It found that

[...] these acts, coupled with the activities of the Danish hunting expeditions which were supported by the Danish Government, the increase in the number of scientific expeditions engaged in mapping and exploring the country with the authorization and encouragement of the Government, even though the expeditions may have been organized by nonofficial institutions, the occasions on which the Godthaab, a vessel belonging to the State and placed at one time under the command of a naval officer, was sent to the East coast on inspection duty, the issue of permits by the Danish authorities, under regulations issued in 1930, to persons visiting the eastern coast of Greenland, show to a sufficient extent —even when separated from the history of the preceding periods - the two elements necessary to establish a valid title

\footnotetext{
1 With the exception of Art. 234, this paper will not elaborate on the content of these provisions and their interpretation. The knowledge of Arctic geography is also implied.

2 On the questions considered in this paper, see in general: Pharand, 1973; Brigham, 1991; Franckx, 1993; Byers, 2013.

3 Art. 1: «The High Contracting Parties undertake to recognise, subject to the stipulations of the present Treaty, the full and absolute sovereignty of Norway over the Archipelago of Spitsbergen, comprising, with Bear Island or Beeren-Eiland, all the islands situated between $10^{\circ}$ and $35^{\circ}$ longitude East of Greenwich and between $74^{\circ}$ and $81^{\circ}$ latitude North, especially West Spitsbergen, North-East Land, Barents Island, Edge Island, Wiche Islands, Hope Island or Hopen-Eiland, and Prince Charles Foreland, together with all islands great or small and rocks appertaining thereto.
} 
to sovereignty, namely: the intention and will to exercise such sovereignty and the manifestation of State activity (PCJI, 1933: 62).

The only presently unsettled question on sovereignty over territory in the Arctic region relates to the small Hans Island, claimed by Canada and by Denmark. Less than a mile in length, it is located at latitude $80^{\circ} 49^{\prime} \mathrm{N}$, in the Nares Strait halfway between Ellesmere and Greenland ${ }^{4}$.

\section{Questions of Sovereignty over the Sea}

In the declaration adopted on 28 May 2008 at Ilulissat (International Legal Materials, 2008: 382), the five States bordering the Arctic Ocean (Canada, Denmark, Norway, Russian Federation, United States) expressed the following position on how international law of the sea applies to Arctic waters:

The law of the sea provides for important rights and obligations concerning the delineation of the outer limits of the continental shelf, the protection of the marine environment, including ice-covered areas, freedom of navigation, marine scientific research, and other uses of the sea. We remain committed to this legal framework and to the orderly settlement of any possible overlapping claims. This framework provides a solid foundation for responsible management by the five coastal States and other users of this Ocean through national implementation and application of relevant provisions. We therefore see no need to develop a new comprehensive international legal regime to govern the Arctic Ocean. We will keep abreast of the developments in the Arctic Ocean and continue to implement appropriate measures.

The reference in the declaration to "law of the sea" seems to cover not only the UNCLOS, but also other applicable treaties and international customary rules. As it appears from the declaration, the most interested States feel that the present international law of the sea is sufficient to deal with Arctic issues and that there is no need to develop a new specific Arctic Ocean regime, as it has been done in several other regional seas 5 . In fact, there are several pending law of the sea disputes in Arctic waters, as the review made hereunder show.

\footnotetext{
4 The 1973 Agreement for the delimitation of the continental shelf between Canada and Denmark does not provide any boundary between points Nos. 122 and 123, situated on the southern and northern coasts of Hans Island, respectively.

5 A distinguished author advocated for «the elaboration of a regional seas agreement for the Arctic that reiterates the general principles in Part XII of the LOSC [= UNCLOS] as well as those in the UNFSA [= the 1995 United Nations Fish Stocks Agreement], including the precautionary approach and the ecosystem approach. The agreement should include specific measures set out in annexes or protocols covering issues commonly addressed in other regional agreements, such as: monitoring, environmental impact assessment, land-based activities, waste management, ocean dumping, contingency planning and emergency response, environmental impacts of oil and gas exploitation, conservation of biodiversity, conservation and management of fisheries, shipping, air pollution and possibly bioprospecting " (De la Fayette, 2008:. 566).
} 


\section{B. Straight Baselines}

As regards the line from which the territorial sea and the other maritime zones are measured, only the Unites States among the five North polar coastal States applies the normal baseline of the low water mark along the whole extent of its coastline, including Alaska ${ }^{6}$. The other four States concerned (Norway, Canada, Denmark and Russia) have established straight baseline systems.

a) On the basis of a Royal Decree of 12 July 1935, Norway drew straight baselines along the Northern part of the country (beyond the Polar Circle, latitude 66 $28.8^{\prime} \mathrm{N}$ ). It was the first time in international practice that a State decided to draw into the sea a continuous series of segments as the basis from where the waters subject to national jurisdiction were measured. The decree mentioned in its preamble «the geographic conditions prevailing on the Norwegian coast» and the need to «safeguard the vital interests of the inhabitants of the northernmost part of the country.»

The baseline runs from Træna, in the county of Nordland, to the boundary with the neighbouring Arctic country (Finland in 1935, then the Soviet Union and now the Russian Federation) in the easternmost part of the fiord of Varanger. The forty-seven segments join forty-eight fixed points located on the mainland, islands or rocks, whose coordinates are specified in the schedule annexed to the decree. The longest segments are those closing Sværholthavet (39 n.m.), Lopphavet (43.6 n.m.) and Vestfjord (40 n.m.).

The 1935 Norwegian decree was the subject matter of a decision rendered by the International Court of Justice on 18 December 1951 in the Fisheries case (United Kingdom v. Norway). The Court found that the method employed by the 1935 Norwegian Decree and the baselines determined by it were «not contrary to international law.» To reach this conclusion, the Court relied on three different and concurring factors of geographic, economic, and historic character (ICJ, 1951: 116) 7 . The decision of the Court greatly influenced the provisions on straight baselines included in the subsequent conventions of codification, namely the Convention on the Territorial Sea and the Contiguous Zone (Geneva, 1958) and the UNCLOS.

Norwegian straight baselines relating to the whole mainland coast are today in force under the regulations laid down by the Royal Decree of 14 June 2002, as amended by Crown Prince Regent's Decree of 10 October 2003.

\footnotetext{
6 See: Scovazzi, 2001: 69. For the relevant maps, see: Scovazzi, Francalanci, Romanò y Mongardini, 1989.

7 The Court rejected the assumption by the United Kingdom that precise limits of length were to be established for the single segments of the straight baseline.
} 
By a Royal Decree of 30 June 1955, Norway established straight baselines around the island of Jan Mayen. By a Royal Decree of 25 September 1970, straight baselines were also established around the islands of the Spitzebergen/Svalbard archipelago (islands of Hopen, Bjørn, Kong Karl, Kvit, Spitzbergen, Nordaustland, Edge).

b) Straight baselines were established by Denmark for the southern (Executive Order No. 629 of 22 December 1976) and the northern (Executive Order No. 176 of 14 May 1980) part of Greenland. The longest segments close Disko Bay (65.6 n.m.), Umanak Fiord (67.2 n.m.), Kane Basin (66.4 n.m.) on the western coast, and some indentations along the northern coast $(67.2 \mathrm{n} . \mathrm{m}$. and $80.1 \mathrm{n} . \mathrm{m}$. for the line nearby Princess Dagmar Peninsula). The list of base-points has been amended by the Royal Decree of 15 October 2004, which sets forth straight baselines around Carey Island. Being characterised by many deep indentations similar to the Norwegian fiords, the coast of Greenland generally qualifies for the drawing of straight baselines ${ }^{8}$.

c) By the Territorial Sea Geographic Coordinates (Area 7) Order of 10 September 1985, Canada established a straight baselines system of 139 segments, which follow almost completely the Canadian Arctic archipelago from the boundary with the United States (Alaska) in the Beaufort Sea to the entrance of the Hudson Strait (between Labrador and Baffin Island) in the Labrador Sea. Some of the longest segments close the Gulf of Amundsen (99.2 n.m.), the Strait of M'Clure (99.5 n.m.), the Lancaster Sound (51.3 n.m.), that is the western and eastern entrances of the Parry Channel. A number of basepoints on the northern coast of the island of Ellesmere are located on the outer edge of ice shelves.

The Canadian order was a response to the voyage by the Polar Sea, a United States Coastguard ship, through the North West Passage, one of the most difficult routes in the world because of its navigational and ice conditions (McDorman, 1986: 243). The voyage, which was made without the previous authorization of Canada, was based on the legal assumption that the waters between the islands of the Canadian archipelago were subject to the regimes of either freedom of navigation (applicable on the high seas) or right of passage (applicable in international straits) (Pharand y Legault, 1984; Pharand, 2007: 3).

As pointed out in a statement made in 1985 in the House of Commons by the Canadian Secretary of State for External Affairs, Mr. Clark, the closing of the Arctic archipelago within this system of baselines served the purpose to ensure national security with respect to a predictable increase in foreign commercial and military navigation:

\footnotetext{
8 However, no detailed analysis has been published to determine whether the single segments comply with the applicable rules on straight baselines.
} 
Many countries, including the United States and the Federal Republic of Germany, are actively preparing for commercial navigation in Arctic waters. Developments are accelerating in ice science, ice technology, and tanker design. Several major Japanese firms are moving to capture the market for icebreaking tankers once polar oil and gas come on stream. Soviet submarines are being deployed under the Arctic ice pack, and the United States Navy in turn has identified a need to gain Arctic operational experience to counter new Soviet deployments. (...) As the Western country with by far the greatest frontage on the Arctic, we must come up to speed in a range of marine operations that bear on our capacity to exercise effective control over the Northwest Passage and our Arctic waters (International Legal Materials, 1985: 1723).

The whole Arctic region, which encompasses land, islands, waters and ice, was considered by Canada as a unity, where the frozen waters played the role of a bridge between the continent and the islands and between one island and the other:

Canada's sovereignty in the Arctic is indivisible. It embraces land, sea, and ice. It extends without interruption to the seaward-facing coasts of the Arctic islands. These islands are joined and not divided by the waters between them. They are bridged for most of the year by ice. From time immemorial Canada's Inuit people have used and occupied the ice as they have used and occupied the land.

The needs to protect the vital interest of the Inuit people and to preserve the environment were also mentioned as reasons for a claim to consider the waters within the baselines as an extent of Canadian historic waters:

The exercise of functional jurisdiction in Arctic waters is essential to Canadian interests. But it can never serve as a substitute for the exercise of Canada's full sovereignty over the waters of the Arctic archipelago. Only full sovereignty protects the full range of Canada's interests. The full sovereignty is vital to Canada's security. It is vital to Canada's Inuit people. And it is vital even to Canada's nationhood. [...]

Our goal is to make the Northwest Passage a reality for Canadian and foreign shipping, as a Canadian waterway. Navigation, however, will be subject to the controls and other measures required for Canada's security, for the preservation of the environment, and for the welfare of the Inuit and other inhabitants of the Canadian Arctic. These baselines define the outer limit of Canada's historic internal waters.

The basis for a historic title is recalled in the preamble of the 1985 Order, which was enacted «whereas Canada has long maintained and exercised sovereignty over the waters of the Canadian Arctic archipelago».

The United States took the position that the Canadian 1985 Order had no legal basis:

The United States position is that there is no basis in international law to support the Canadian claim. [...] To do so would constitute acceptance of full Canadian control of the Northwest Passage and would terminate U.S. navigation rights through the Passage under international law. Acceptance would also complicate our maintenance of 
navigation rights in other areas, such as Indonesia and the Aegean» (Acting Assistant Secretary, 1996: 118).

The United States added that the Canadian measures affected navigational rights through waters constituting a strait used for international navigation and subject to the transit passage regime.

On 11 January 1988 Canada and the United States signed an agreement on Arctic cooperation. The parties affirm that «navigation and resource development in the Arctic must not adversely affect the unique environment of the region and the well-being of its inhabitants» (Art. 2) and undertake «to facilitate navigation by their icebreakers in their respective Arctic waters and to develop cooperative procedures for this purpose» (Art. 3). With regard to the 1985 Canadian claim, the United States «pledges that all navigation by U.S. icebreakers within waters claimed by Canada to be internal will be undertaken with the consent of the Government of Canada» (Art. 3). However, this undertaking is accompanied by a disclaimer clause, so as not to prejudice the legal positions of the parties ${ }^{9}$.

Also, the member States of the European Community jointly stated, in a note dated 9 July 1986, that the Canadian baselines did not conform to the geographical requirements and that they could not recognise the validity of a historic title as justification for the baselines drawn in that order. In a note of reply of 7 August 1986, the Canadian Department of External Affairs stressed the peculiarities of the waters enclosed by the baselines and their physical unity with the surrounding land:

The baselines give precise definition to Canada's historic title to the waters and take into account the unique geographic, climatic, physical end ecological characteristics of the area. They reflect the close relationship between the islands and waters of the archipelago and their unity with the mainland as its northward prolongation or projection, the absence of customary international navigation through channel that are ice-covered for all or most of the year, and the economic interests peculiar to the region concerned as clearly evidenced by long usage.

d) By a Decree of 15 January 1985 of the Council of Ministers, the Soviet Union established straight baselines along the Arctic Ocean. This legislation, which is today applied by the Russian Federation, gives the coordinates of 391 base points along the continental coast, from the boundary with Norway to Cape Neshkan, in the Chukchi Sea. The lines follow most of the coastline along the seas of Barents, Kara, Laptev, East Siberia, and Chukchi. The Decree also provides that the waters of the White Sea,

\footnotetext{
9 «Nothing in this agreement of cooperative endeavour between Arctic neighbours and friends nor any practice thereunder affects the respective positions of the Governments of the United States and of Canada on the Law of the Sea in this or other maritime areas or their respective positions regarding third parties».
} 
south of the line connecting Cape Svyatoy and Cape Kanin, the waters of Cheshskaya Bay, south of the line connecting Cape Mikulkin and Cape Svyatoy (Timanskiy), and the waters of Baydaratskaya Bay, southeast of the line connecting Cape Yuribeysalya and Cape Belushiy, are internal waters, as waters historically belonging to the Soviet Union. The closing lines of the three historical bays measure respectively 70.4 n.m. (White Sea), 35.6 n.m. (Cheshskaya) and 54.2 n.m. (Baydaratskaya). Separate sets of base points are also located on single islands: Kolguev (two points); three of the islands of the Zemlya Frantsa-Iosifa archipelago, namely Zemlya Alexandry (four points), Zemlya Georga (fourteen points), Zemlya Gallya (four points); one of the islands of the archipelago of Novaya Sibir (6 points); Vrangelya (ten points).

Other islands, such as Novaya Zemlya, the archipelago of Severnaya Zemlya and most of the islands of the archipelago of Novaya Sibir are joined to the continent by segments of the straight baselines. This has the effect of including within the Russian internal waters three sea areas which could be considered international straits, namely the Kara Strait (connecting the Barents and Kara Seas), the Vil'kitski and Sokal'skii Straits (connecting the Kara and Laptev Seas), and the Sannikov and Dimitri Laptev Straits (connecting the Laptev and East Siberian Seas). It can be questioned whether these lines follow the general direction of the coast ${ }^{10}$.

All the above-mentioned straits are located along the Northern Sea Route, which is composed of a series of shipping routes, running north of the Russian coast, through the seas of Kara, Laptev, East Siberia and Chukchi, and connecting the Atlantic and the Pacific Oceans. The position of the Soviet Union was that none of these straits is used for international navigation. The present position of the Russian Federation does not appear to have changed. The United States took the opposite view. It protested against the Soviet straight baselines system and in 1992 «challenged the Russian straight baseline closing access to the Barents Sea port of Murmansk» (Acting Assistant Secretary, 1996: 100).

On 14 September 1990, the Soviet Union enacted the Regulations for Navigation of the Seaways of the Northern Sea Route. As stated in Art. 2:

The Regulations shall, on the basis of non-discrimination for vessels of all States, regulate navigation through the Northern Sea Route for the purpose of ensuring safe navigation and preventing, reducing, and keeping under control marine environment pollution from vessels since the specifically severe climatic conditions that exist in the Arctic Regions and the presence of ice during the most part of the year bring about obstacles, or increased danger, to navigation while pollution of sea of the Northern

\footnotetext{
10 However, any assessment on the fact that the baselines do not depart to any appreciable extent from the general direction of the coast is largely dependent on the scale of the map used.
} 
Coast of the USSR might cause great harm to the ecological balance or upset it irreparably, as well as inflict damage on the interests and well-being of the North peoples.

The Regulations set forth several requirements for navigation through the Route. For example, the owner or master of the vessel must submit a notification and request for leading to the Administration of the Northern Sea Route. The Administration may carry out an inspection of the vessel while it navigates the route if unfavourable ice, navigational, hydrographic, weather and other conditions occur that might endanger a vessel, or where there is a threat of polluting the marine environment or the coast. Compulsory icebreaker-assisted pilotage is provided for the straits of Vil'kitski, Sokal'skii, Sannikov, and Dimitri Laptev (Brubaker, 2005: 144). In the other regions, the Administration can prescribe one type of leading as determined by the circumstances (leading along recommended routes, aircraft-assisted leading, conventional pilotage, icebreaker leading, or icebreaker-assisted pilotage). The Administration provides vessels with navigational information and leading and rescue services. Vessels must have on board a certificate of due financial security for civil liability of the owner for any damage caused by pollution to the marine environment and the coast. Payments for the services rendered to vessels are collected in accordance with the approved rates ${ }^{11}$. Again, the conformity with international law of the measures adopted by the Soviet Union (and today confirmed by Russia) has been questioned by the United States, especially with regard to their incidence on passage through maritime straits.

\section{C. National Legislation on National Maritime Zones}

All five Arctic coastal States have enacted legislation that provides for the establishment of national maritime zones according to the limits set forth in the UNCLOS, namely a twelve mile territorial sea and a 200-mile exclusive economic zone. The legislation of Norway (Act No. 91 of 17 December 1976, relating to the exclusive economic zone off the mainland coast) ${ }^{12}$, the United States (Proclamation 5030, confirming an exclusive economic zone), Canada (1996 Oceans Act), the Russian Federation

\footnotetext{
11 Institutions in Russia, Norway and Japan established the International Northern Sea Route Programme (INSROP) aimed at promoting commercial shipping along the northern Russian coast. INSROP was sponsored by Central Marine Research \& Design Institute, Russia, the Fridtjof Nansen Institute, Norway, and Ship \& Ocean Foundation, Japan. It was divided into four sub-programmes, namely: natural conditions and ice navigation; environmental factors; trade and commercial shipping aspects; and political, legal and strategic factors. In 1996 the International Evaluation Committee, which was established to review the achievements made during INSROP's first phase, recommended that the convening of an intergovernmental conference on Arctic navigation be explored and discussed during the second phase (see Northern Sea Route: Future and Perspective, 1996). For the first time in 2009, two commercial ships were reported to have navigated through the whole Northern Sea Route, saving about 4,000 nautical miles with respect to the ordinary route linking the Far East to Europe.

12 Norway has established a 200-mile fishery zone around the island of Jan Mayen (Royal Decree No. 4 of 23 May 1980).
} 
(1998 Federal Act, defining the status of the exclusive economic zone) and Denmark (2004 Executive Order, relating to the exclusive economic zone of Greenland) can be recalled in this regard. In certain cases, the legislation generally applies to all the national territory, including the Arctic region; in other cases special legislation has been enacted for the Arctic region. However, some peculiarities exist in the cases of Canada and Norway.

a) In 1970, Canada, by the Arctic Waters Pollution Prevention Act, adopted special measures for the regulation of navigation and the prevention of pollution from vessels within a one hundred mile zone from the nearest Canadian land in Arctic waters between $60^{\circ}$ latitude North and $141^{\circ}$ longitude West. At that time, Canada was concerned about the environmental risk of a project planned by United States companies to develop a route of navigation through the North West Passage and within the islands of the Canadian Arctic archipelago to be used by ice-strengthened super-tankers carrying oil extracted in Alaska.

The measures that have been adopted under the 1970 Act can today be justified under Art. 234 UNCLOS $^{13}$. The 1970 Act was subsequently replaced by the Arctic Waters Pollution Prevention Act 1985. A number of regulations and orders have been adopted on the basis of it. Lastly, in 2009, the Act was amended to enforce national environmental legislation and shipping regulations in Arctic waters up to 200 n.m., doubling the area of coverage previously established.

b) By regulations adopted in 1977, Norway established a 200-mile fishery protection zone around the Svalbard archipelago (also called Spitzbergen archipelago). However, the right of Norway to exercise exclusive rights over the living resources of such a zone, as well as over the mineral resources of the continental shelf around the $\operatorname{archipelago~}^{14}$, is put into question by several State parties to the 1920 Spitzbergen Treaty that granted Norway sovereignty over the archipelago. These States rely on Art. 3 of the treaty that provides as follows:

The nationals of all the High Contracting Parties shall have equal liberty of access and entry for any reason or object whatever to the waters, fords and ports of the territories specified in Article 1; subject to the observance of local laws and regulations, they may carry on there without impediment all maritime, industrial, mining and commercial operations on a footing of absolute equality.

\footnotetext{
13 See infra, para. 3.D.

14 Including the continental shelf beyond 200 nautical miles as it appears from the observations made by the Russian Federation and Spain to the submission presented by Norway to the Commission on the Limits of the Continental Shelf (Commission on the Limits of the Continental Shelf, Summary of the Recommendations of the Commission on the Limits of the Continental Shelf in Regard to the Submission Made by Norway in Respect of Areas in the Arctic Ocean, the Barents Sea and the Norwegian Sea on 27 November 2006, 2006).
} 
They shall be admitted under the same conditions of equality to the exercise and practice of all maritime, industrial, mining or commercial enterprises both on land and in the territorial waters, and no monopoly shall be established on any account or for any enterprise whatever. [...].

The position of the States in question is that, as they have been granted under the Spitzbergen Treaty rights relating to the exploitation of resources in the islands and the territorial waters of the archipelago, all the more reason they are entitled to exercise the same rights in the maritime zones adjacent to the territorial waters, such as the continental shelf or the exclusive economic zone. The position of Norway is that the rights granted to the other parties are limited to the territorial sea, as other maritime zones spaces are not mentioned in the treaty. The question is complicated by the fact that the legal concepts of continental shelf and exclusive economic zone did not exist at the time when the Spitzbergen Treaty was concluded ${ }^{15}$, but are the result of the subsequent evolution of international law of the sea.

\section{D. Navigation in Ice-Covered Waters}

Navigation needs to be regulated at the world level. Maritime mobility, which is the most important aspect of freedom of the sea, is a major concern for several countries, including the main powers. In a number of its provisions, the UNCLOS sets forth the basic concepts that generally accepted international rules and standards apply to pollution from vessels and that rules in this matter are established through the "competent international organization» ${ }^{16}$ or "general diplomatic conference.» See, for example and for various purposes, Art. 21, para. 2 (laws and regulations of the coastal State relating to innocent passage), Art. 41, para. 4 (sea lanes and traffic separation schemes in straits used for international navigation) and Art. 211, para. 6, a (pollution from vessels).

If different measures were taken by the coastal States relating to matters such as the design, construction, equipment, operation or manning of ships, innocent passage in the territorial sea or transit through international straits would be made impossible. Rather than coastal States acting unilaterally, it is far more desirable if shipping measures, such as traffic separation schemes, recommended routes, deep-water routes, areas to be avoided, compulsory pilotage or vessel traffic services, are adopted at the international level through negotiation and cooperation among the interested countries.

15 They were codified by the Convention on the Continental Shelf (Geneva, 1958) and the UNCLOS, respectively.
16 This is understood as an implicit reference to the International Maritime Organization (IMO). 
However, regulation at the world level does not exclude the application of special provisions relating to navigation in certain areas. Art. 234 of the UNCLOS itself contains a provision devoted to «ice-covered areas ${ }^{17}$ :

Coastal States have the right to adopt and enforce non-discriminatory laws and regulations for the prevention, reduction and control of marine pollution form vessels in ice-covered areas within the limits of the exclusive economic zone, where particularly severe climatic conditions and the presence of ice covering such areas for most of the year creates obstructions or exceptional hazards to navigation and pollution of the marine environment could cause major harm or irreversible disturbance of the ecological balance. Such laws and regulations shall have due regard to navigation and the protection and preservation of the marine environment based on the best available scientific evidence.

It is not clear if Art. 234 applies to the waters surrounding the Antarctic continent, which are also ice-covered. It depends on whether there are "coastal States» and «exclusive economic zones» in the situation of claims, counterclaims, objections to claims, and objections to counterclaims, which characterizes the Pandora's box of zones of maritime jurisdiction in Antarctica. But there is no doubt that Art. 234 does apply to Arctic waters where coastal States exist and they have established exclusive economic zones.

As in the case of other legal provisions which enter into too detailed descriptions, subtle questions of interpretation are hidden in the wording of Art. 234. For example:

- At what temperature do climatic conditions become "particularly severe»?

- How many days or months is «most of the year»?

- Do the laws and regulations adopted by the coastal States for ice-covered areas apply also in the part of the year when these areas are not covered by ice?

- What happens if, in certain years, the waters are ice-covered for most of the year, but in other years they are not, considering that the precise calculation of the duration of ice-coverage can only be made at the end of each year?

- Can a situation where ice covers the area for most of the year, but the climatic conditions are not particularly severe, be envisaged?

- In what cases is a hazard to navigation «exceptional»?

- In what cases can pollution of the marine environment cause a «major harm»?

- In what cases is a disturbance of the ecological balance «irreversible»?

17 For more on the negotiations relating to Art. 234, see: Nordquist, Rosenne y Yankov, 1991; Brubaker, 2000: 224; Scovazzi, 2009: 371 . 
The above mentioned questions may seem frivolous or academic. What is most important is to seize the spirit of Art. 234 and its two main messages. First, in marine ice-covered areas unilateral action by coastal States is allowed by the UNCLOS, provided that the relevant measures are non-discriminatory. Second, in such areas a fair balance has to be struck between navigation, on the one side, and protection and preservation of the marine environment, on the other, with the consequence that an overarching status cannot be automatically granted to navigation alone.

However, Art. 234 hides another question of interpretation, which is far from being frivolous or academic:

- Do the words "within the limits of the exclusive economic zone» refer to the space between the inner and the outer limits of such a zone (that is, to the 188-mile ice-covered waters included between the 12-mile limit of the territorial sea and the 200-mile limit of the exclusive economic zone)? Or do the words in question refer to the space between the coastline and the outer limit of the exclusive economic zone (that is, to the whole 200-mile belt, including the 12-mile territorial sea)?

The difference between the two interpretations is far from being trivial. It implies a crucial question: can the coastal State adopt the laws and regulations allowed by Art. 234 in regard to innocent passage through its territorial sea and transit passage by way of international straits, as Canada and the Russian Federation have done in their legislation on straight baselines? ${ }^{18}$ Art. 234 does not provide any clear-cut answer.

\section{E. Continental Shelf Beyond 200 Nautical Miles}

The completely unsettled question of the limits of outer continental shelf claims in the Arctic region is a major obstacle for any activity taking place in areas of seabed claimed by one or more Arctic coastal States as belonging to its outer continental shelf.

In 2001, the Russian Federation presented to the Commission on the Limits of the Continental Shelf a submission for the establishment of the outer limits of its continental shelf beyond 200 n.m. in the Barents Sea, the Central Arctic Ocean, the Bering Sea, and the Sea of Okhotsk. As far as the Arctic region is concerned, the Russian submission includes a vast portion of seabed, reaching the North Pole. Some States, including Denmark, Canada, Norway, and the United States, made observations on it. For instance, the United States remarked that the Alpha-Mendeleev ridge system is not a submerged prolongation of the land mass of Russia and that

\footnotetext{
18 Supra, para. 3.B.
} 
the Lomonosov Ridge is not a natural component of the continental margins of either Russia or any other State. Canada and Denmark reserved their position with regard to any question of delimitation of continental shelf between themselves and the Russian Federation. In 2002, the Commission made its recommendations on the submission, asking the Russian Federation to make a revised submission in regard to the Central Arctic Ocean, based on the findings contained in the recommendations. A partial revised submission was presented by the Russian Federation in 2013. It is limited to the Sea of Okhotsk and does not include Arctic waters.

In 2006, Norway presented to the Commission a submission for the establishment of the outer limits of its continental shelf beyond 200 n.m. in the Norwegian Sea, the Barents Sea, and the Arctic Ocean. In 2009, the Commission made its recommendations on the submission.

The submissions presented in 2009, 2012, and 26 November 2014 by Denmark relate, respectively, to the areas north of the Faroe Islands, south of Greenland, and north-east of Greenland. On 15 December 2014 Denmark presented a fourth submission on the limits of the continental shelf north of Greenland. The Danish claim crosses the seabed of the Arctic Ocean, and reaches, in certain areas, as far as the 200-mile limit from the Russian, Canadian, and Norwegian coasts. The day after Denmark's submission, the Russian Ministry of Foreign Affairs issued a comment, stating, inter alia, as follows:

On 15 December, Denmark requested that the Commission on the Limits of the Continental Shelf (CLCS) extend the borders of a continental shelf sector, located north of Greenland, by 200 nautical miles from the coast in line with the 1982 United Nations Convention on the Law of the Sea. Russia was well aware of the Danish side's plans in this respect. Moreover, it became obvious long ago that Denmark would claim the right to own an expanded continental shelf sector below or even above the North Pole. Russia will voice similar claims in line with its revised request, which is currently being drafted. It is precisely with due consideration for this circumstance that our countries have cooperated actively on this issue, throughout the entire duration of drafting Arctic claims, and they will continue to cooperate on this issue.

It should be noted that the CLCS is not authorised to «allot» the relevant continental shelf sector to any specific country or to demarcate water surfaces. After assessing the submitted scientific data, the CLCS is called on to decide whether a specific area falls under the continental shelf category, whether it is an underwater extension of the continent, or whether it is a deep section of the seabed, which no country can claim.

Possible adjoining sections of our countries' continental shelf in the high Arctic latitudes will be demarcated on a bilateral basis, through negotiations and in line with 
international law. However, the CLCS should first confirm that the seabed sections to which Russia and Denmark are laying claim are part of the continental shelf. This issue cannot be solved in a day or two. Considering the CLCS's current work load, the Danish claim will be reviewed not earlier than 10 to 15 years from now, according to current estimates.

On 17 and 29 December 2014, Norway and Canada issued notes aiming at preserving their claims to an extended continental shelf, which overlap with the Danish claim.

The submission presented by Canada in 2013 is limited to the Atlantic Ocean and does not include the Arctic waters. Canada intends to submit information on the limits of the continental shelf beyond 200 nautical miles in the Arctic Ocean at a later date.

No submission can be presented by the United States until it becomes a party to the UNCLOS.

\section{F. Maritime Delimitations}

For the time being, the following treaties have been concluded to delimit national maritime zones in the Arctic:

In 1957, Norway and the Soviet Union delimited the territorial sea off their land boundary in the Varangerfjord.

In 1973, Canada and Denmark delimited the continental shelf through Davis Strait, Baffin Bay, Nares Strait, and Robeson Channel for a distance of about 1,450 n.m., covering a great part of the maritime boundary between the two States.

In 1981, Iceland and Norway, following the recommendations made by a Conciliation Commission, delimited the continental shelf between Iceland and the island of Jan Mayen.

In 1995 , on the basis of a judgment rendered in 1993 by the International Court of Justice, Denmark and Norway delimited the continental shelf and the superjacent waters between Greenland and Jan Mayen. The Court found that a delimitation by the median line would disregard the geography of the coastal fronts of eastern Greenland and of Jan Mayen and that, in light of the disparity of coastal lengths, the median line should be adjusted or shifted in such a way as to effect a delimitation closer to the coast of Jan Mayen.

In 1997, Denmark and Iceland agreed on their maritime boundary in the area between Greenland and Iceland. The boundary reaches the triple point Norway (Jan Mayen)Denmark (Greenland)-Iceland. 
In 1990, the Soviet Union and the United States defined their maritime boundary in the Bering and Chukchi Seas, following in the Arctic region the meridian $168^{\circ} 58^{\prime} 37$ " W. However, the agreement has not yet entered into force, because of the lack of ratification by the Russian Federation.

In 2006, Denmark and Norway delimited the continental shelf and the fisheries zones in the area between Greenland and the Svalbard.

In 2010, Norway and the Russian Federation concluded a treaty on the maritime delimitation in the Barents Sea and the Arctic Ocean (Henriksen y Ulfstein, 2011: 1).

A number of boundaries have still to be settled, including the lateral boundary in the Beaufort Sea between Canada and the United States and the boundary between Canada and Denmark in the Lincoln Sea, as regards North Greenland and the Queen Elizabeth Islands.

\section{Appendix: Maps of Straight Baselines Systems}

The maps — reproduced from Scovazzi, Francalanci, Romanò y Mongardini (eds.), 1989-, show the straight baselines systems established in the Arctic area by Canada (map 1), Denmark (maps 2-3), Norway (map 4) and the Soviet Union, now Russian Federation (maps from 5 to 11). 


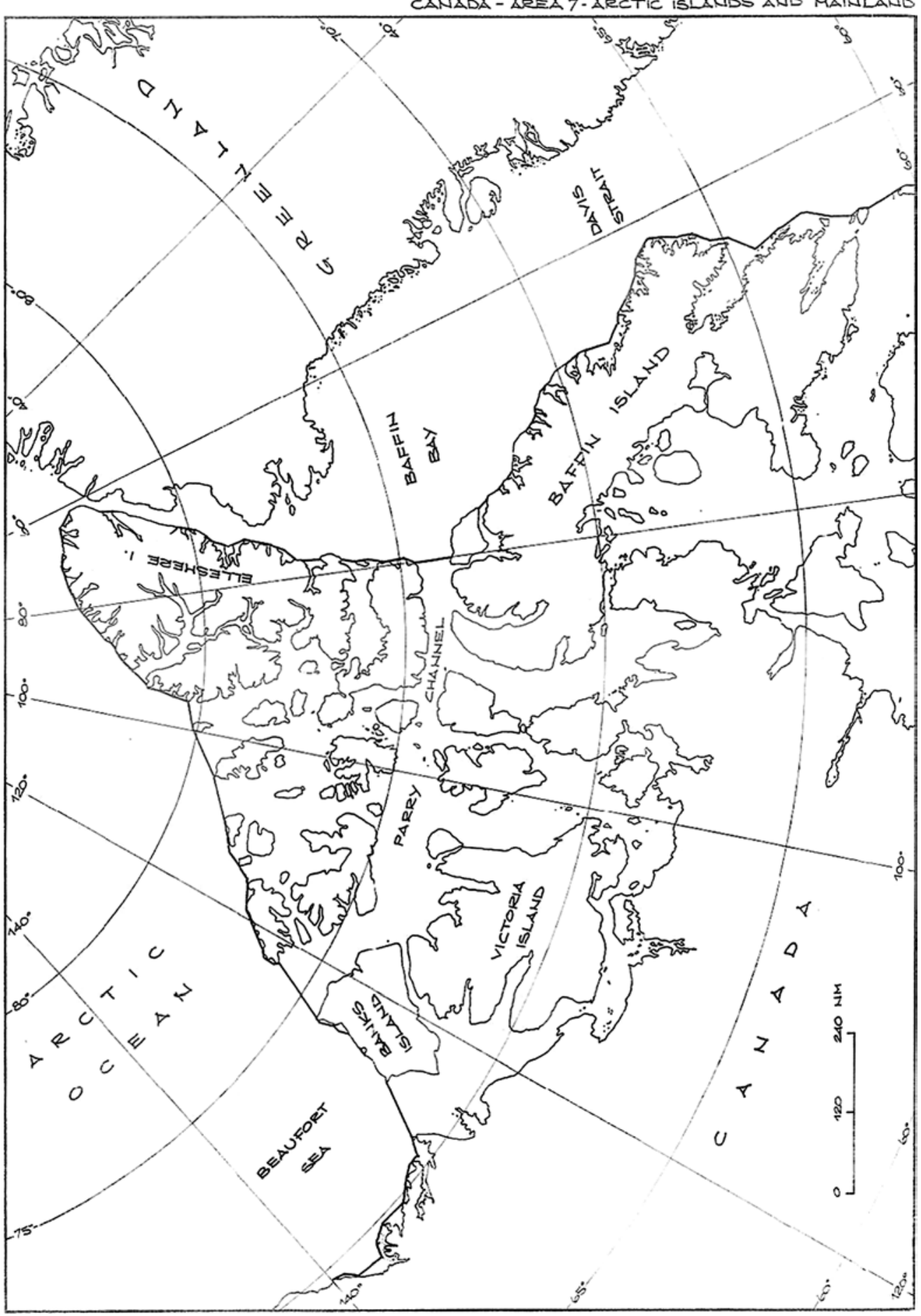




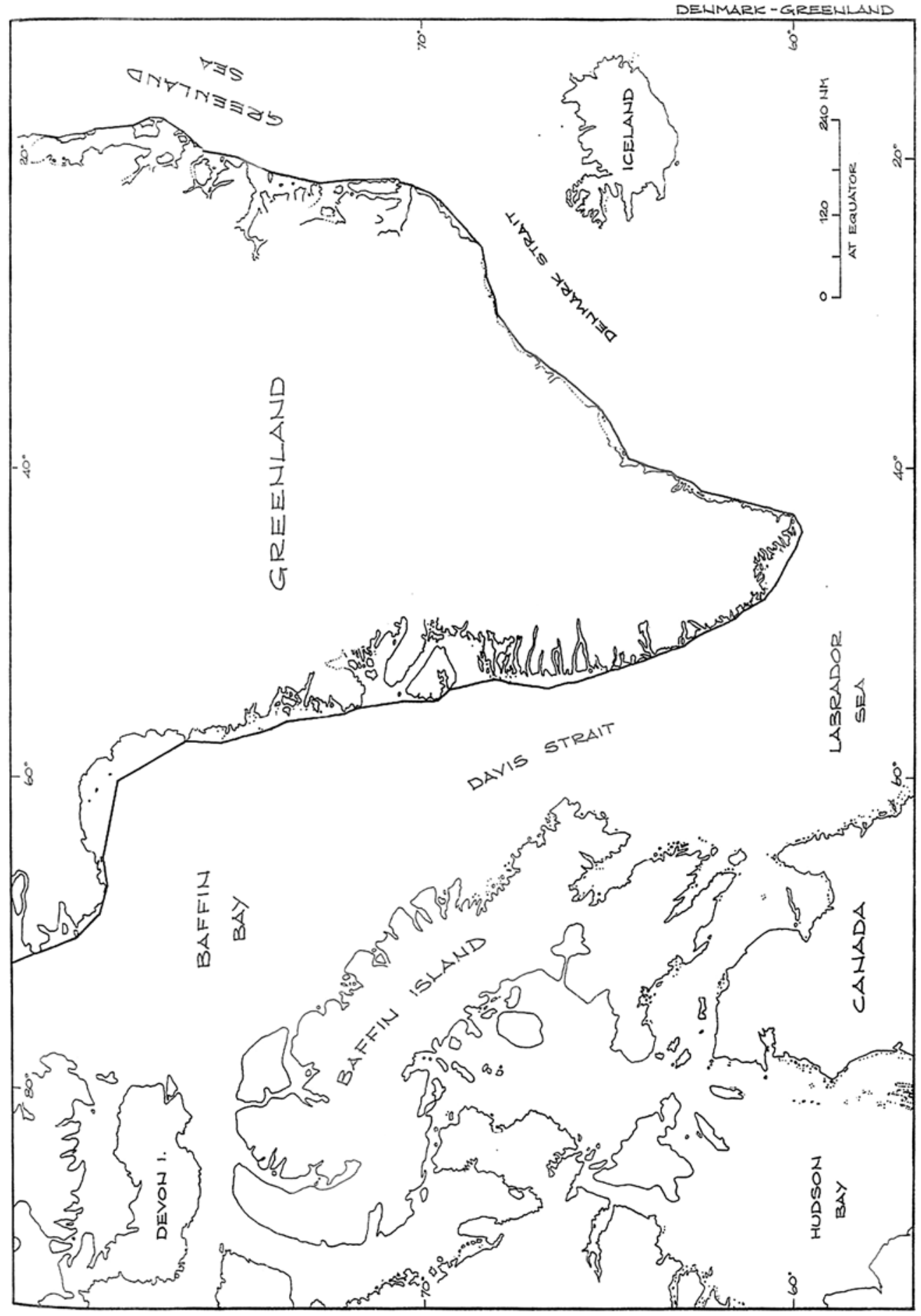

Agenda Internacional, XXIII (34) 2016 


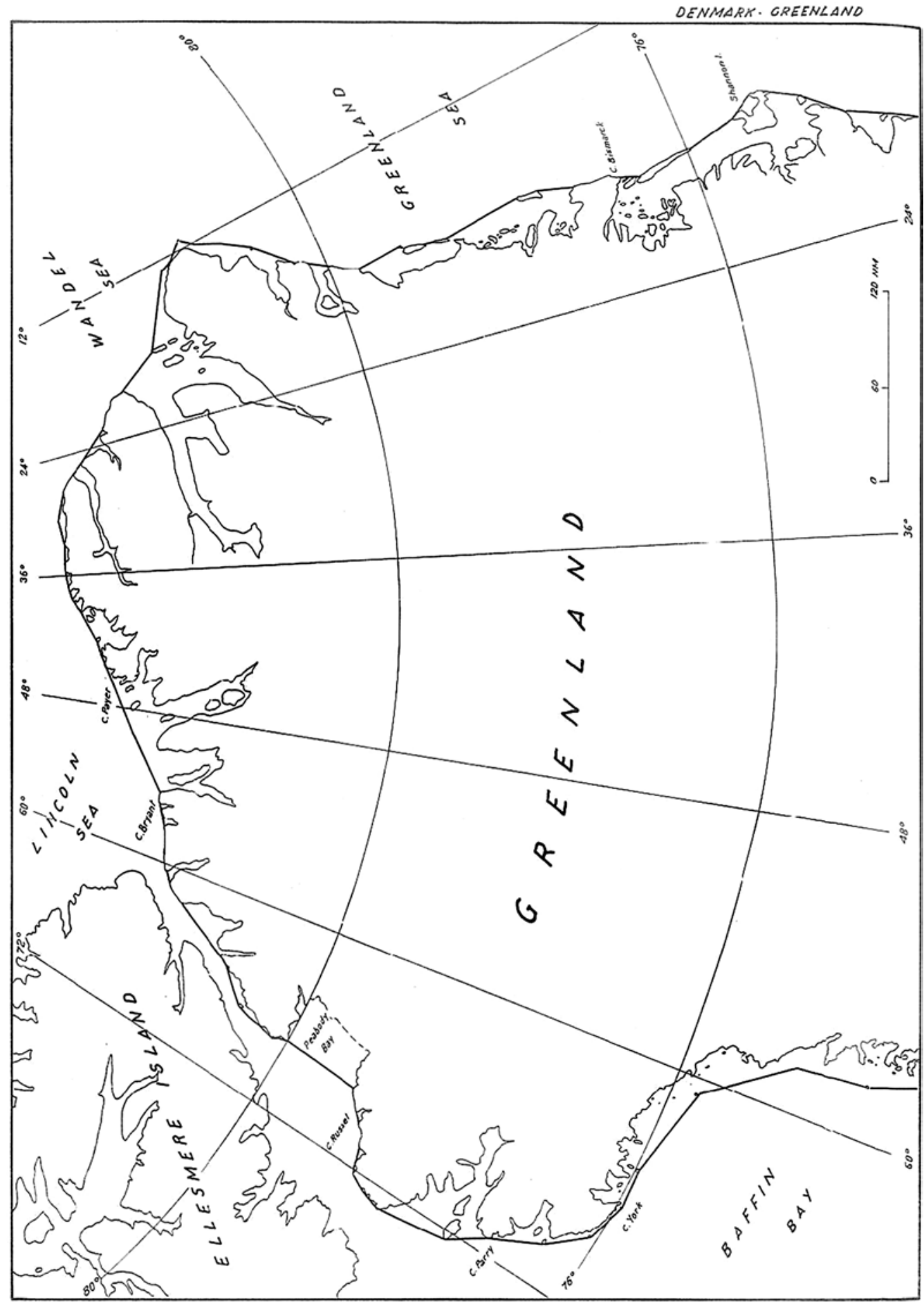

Agenda Internacional, XXIII (34) 2016 
Tullio Scovazsi

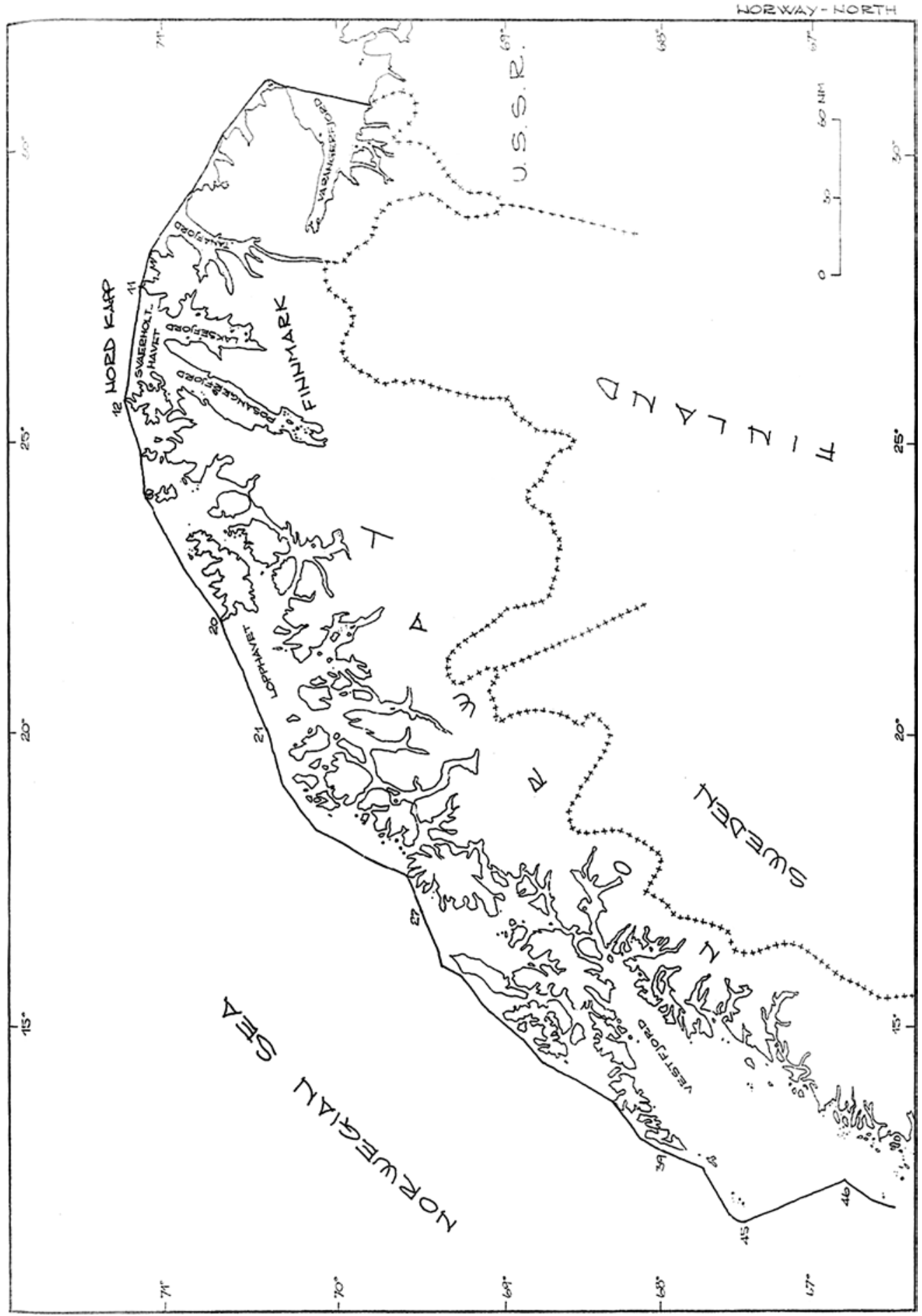

Agenda Internacional, XXIII (34) 2016 
SOVIET UNION.

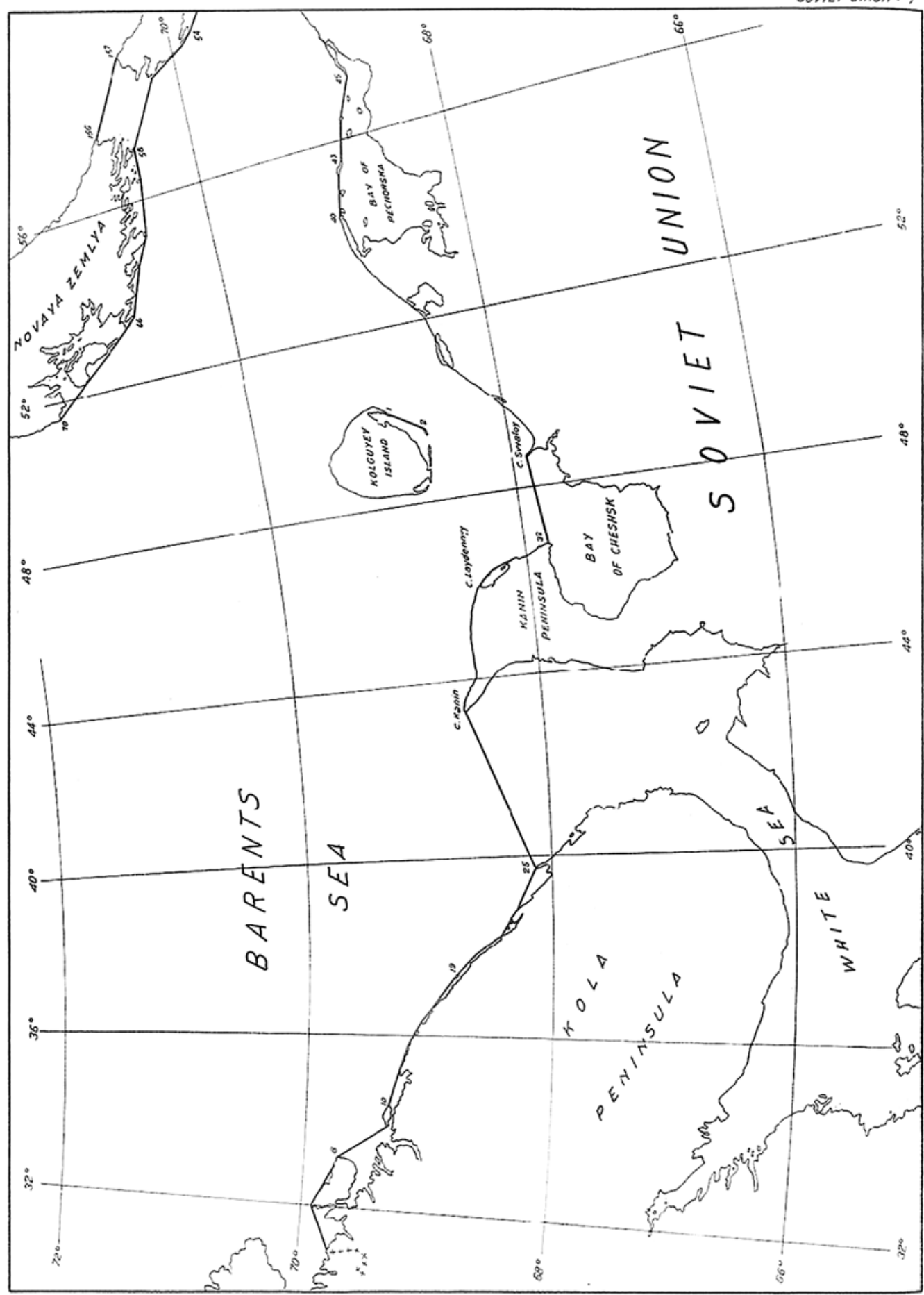

Agenda Internacional, XXIII (34) 2016 


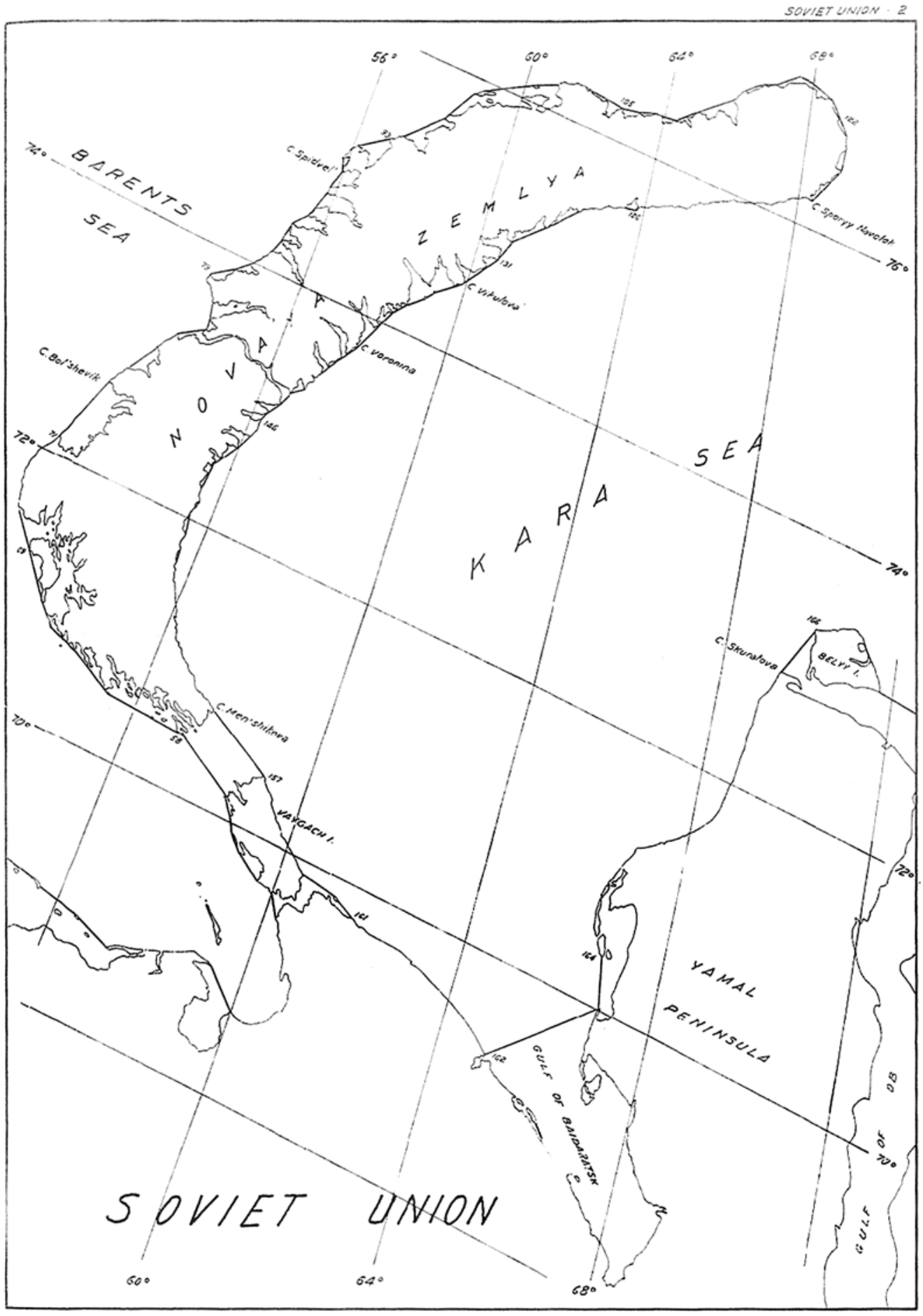


La soberanía sobre tierra y mar en el área ártica

SOVIET UNION-3

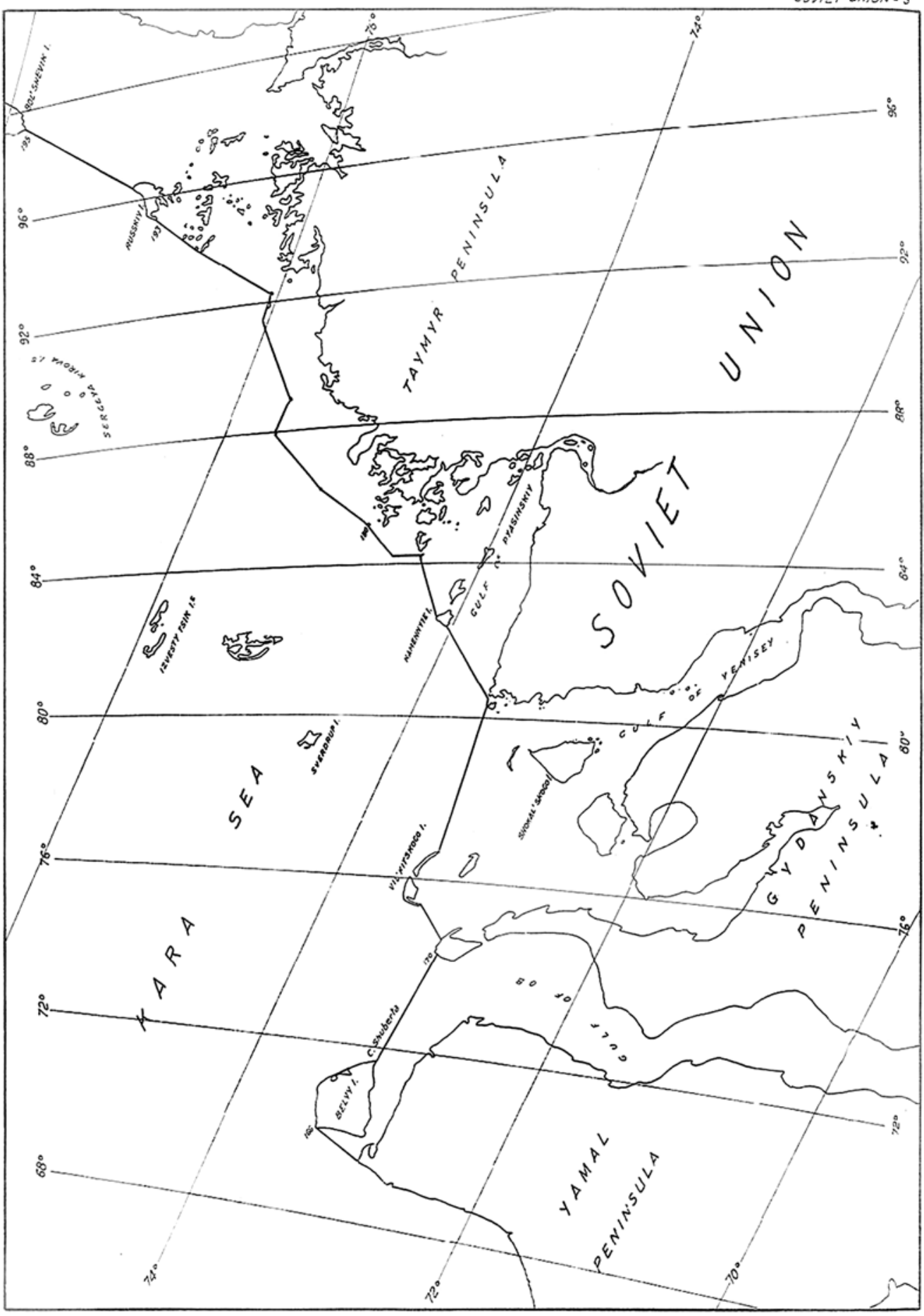

Agenda Internacional, XXIII (34) 2016 


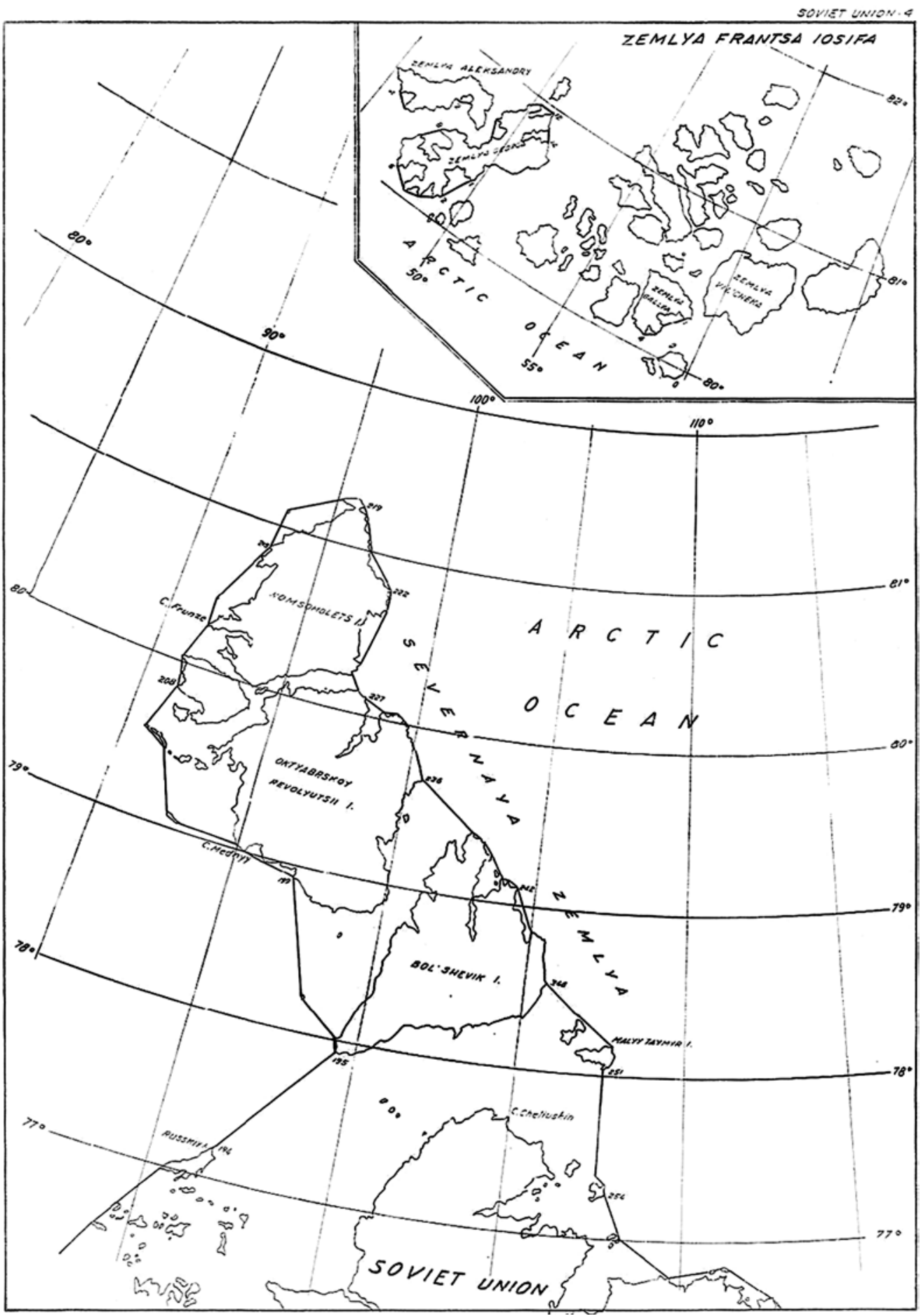

Agenda Internacional, XXIII (34) 2016 


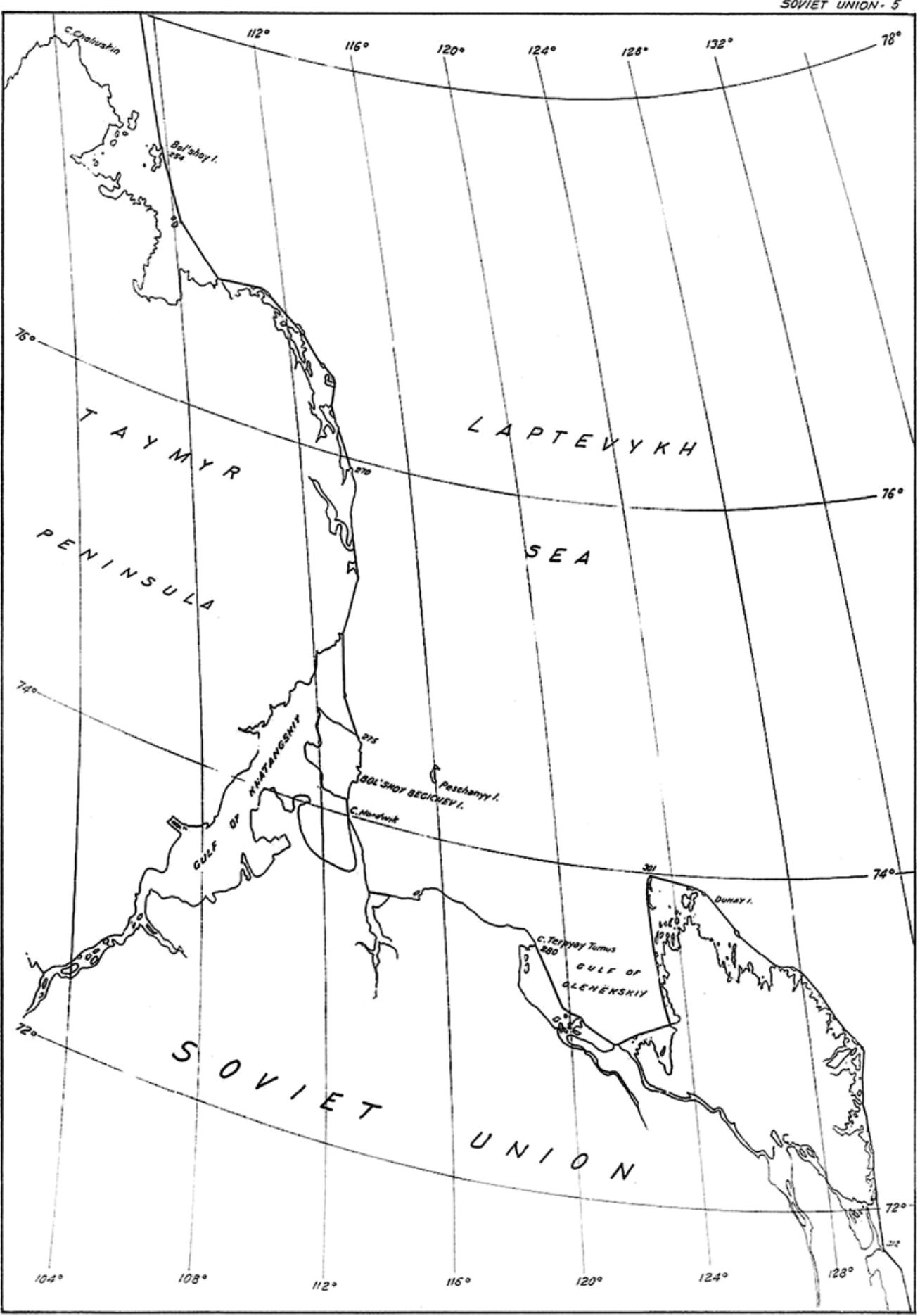

Agenda Internacional, XXIII (34) 2016 


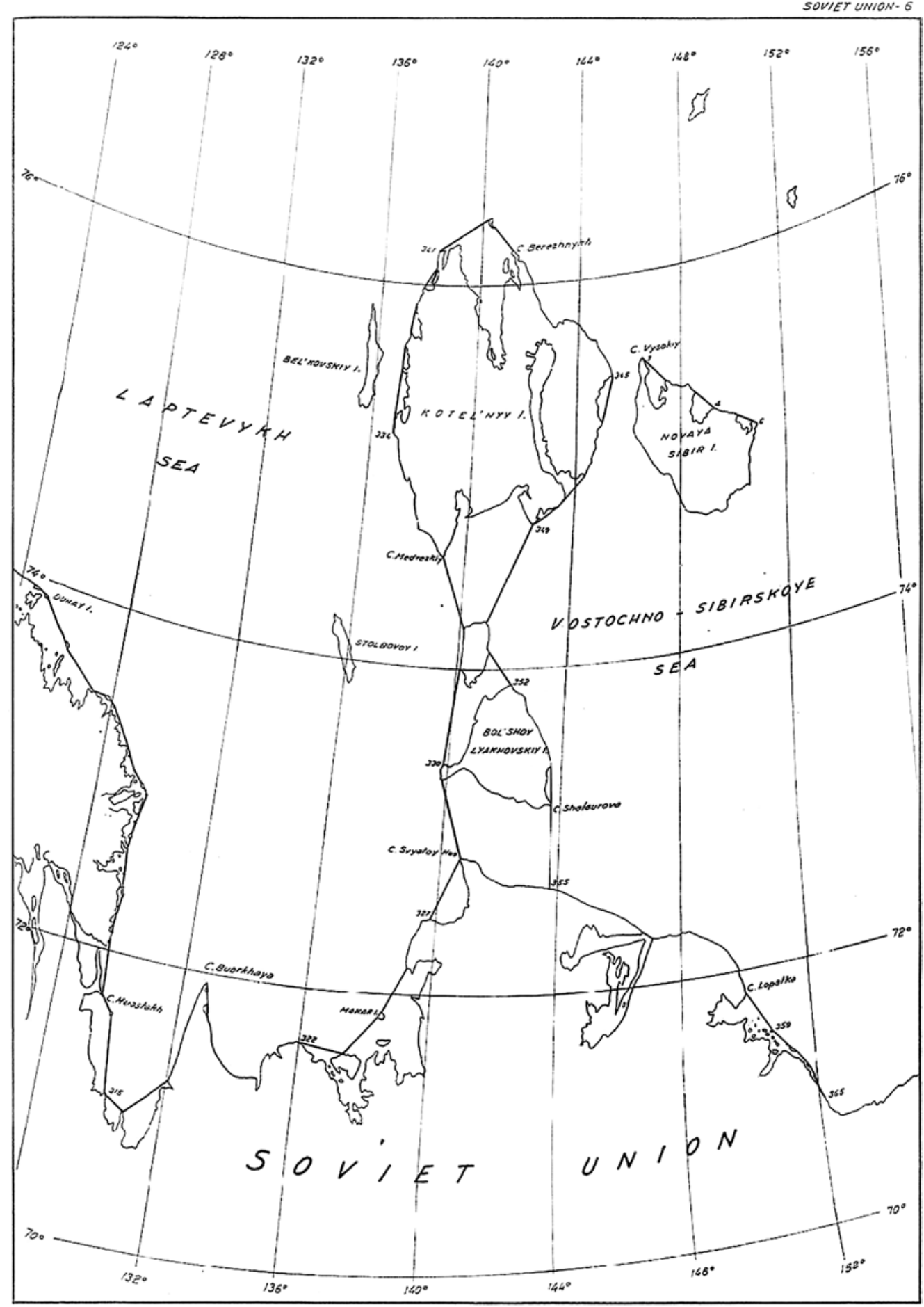




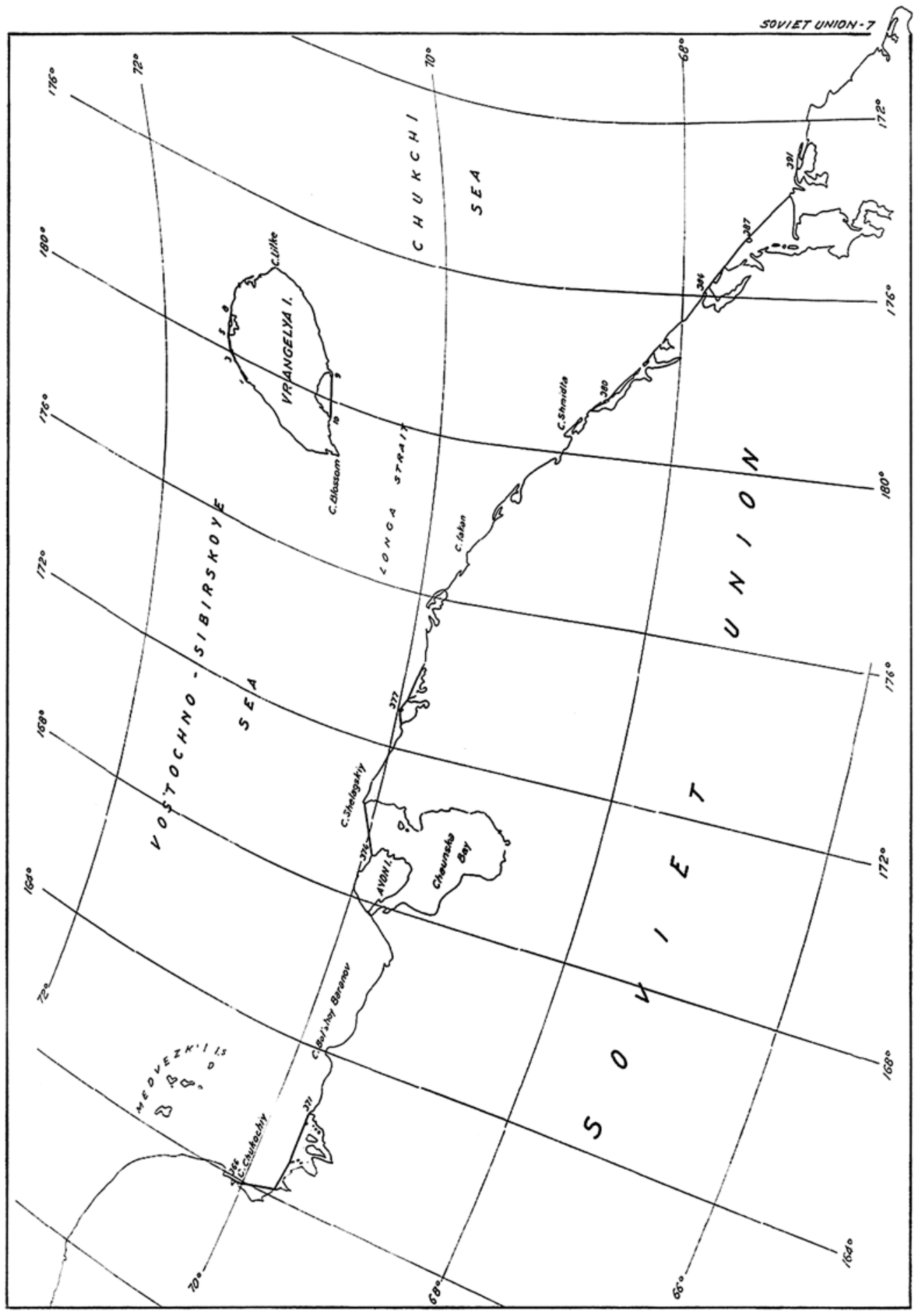

Agenda Internacional, XXIII (34) 2016 


\section{References}

Acting Assistant Secretary (1996). Letter of 26 February 1986 by the Acting Assistant Secretary to a senator of the United States. En J. Ashley Roach y Robert W. Smith. United States Responses to Excessive Maritime Claims. Boston: Martinus Nijhoff Publishers.

Brubaker, R. Douglas (2005). The Russian Arctic Straits. Leiden y Boston: Martinus Nijhoff.

Brubaker, R. Douglas (2000). Regulation of Navigation and Vessel-Source Pollution in the Northern Sea Route: Article 234 and State Practice. En Davor Vidas (Ed.), Protecting the Polar Marine Environment: Law and Policy for Pollution Prevention. Cambridge University Press. http://dx.doi.org/10.1017/cbo9780511494635.012

Brigham, Lawson W. (Ed.) (1991). The Soviet Maritime Arctic. Londres: Naval Institute Press.

Byers, Michael (2013). International Law and the Arctic. Cambridge University Press. http:// dx.doi.org/10.1017/cbo9781107337442

De la Fayette, Louise Angélique (2008). Oceans Governance in the Arctic. International Journal of Marine and Coastal Law, 23(3).

Franckx, Erik (1993). Maritime Claims in the Arctic: Canadian and Russian Perspectives. Dordrecht, Boston y Londres: Martinus Nijhoff Publishers.

Henriksen, Tore y Geir Ulfstein (2011). Maritime Delimitations in the Arctic: The Barents Sea Treaty, in Ocean Development and International Law. http://dx.doi.org/10.1080/009 08320.2011 .542389

ICJ (1951). Reports of Judgments. Advisory Opinions and Orders.

McDorman, Ted L. (1986). In the Wake of the Polar Sea: Canadian Jurisdiction and the Northwest Passage. En Marine Policy, 1986. http://dx.doi.org/10.7202/042763ar

Nordquist, Myron H., Shabtai Rosenne y Alexander Yankov (Eds.) (1991). United Nations Convention on the Law of the Sea - A Commentary, IV.

PCIJ (1933). Collection of Judgments. Series A/B, No. 53 (Legal Status of Eastern Greenland).

Pharand, Donat (2007). The Arctic Waters and the Northwest Passage: A Final Revisit. En Ocean Development and International Law. http://dx.doi.org/10.1080/00908320601071314

Pharand, Donat (1973). The Law of the Sea of the Arctic: With Special Reference to Canada. En Artic Institut of North America. Disponible en: <http://arctic.journalhosting.ucalgary.ca/arctic/index.php/arctic/article/viewFile/3065/3041>.

Pharand, Donat y Leonard H. Legault (1984). Northwest Passage: Arctic Straits. http://dx.doi. org/10.1080/00908320601071314

Scovazzi, Tullio (2009). Legal Issues Relating to Navigation through Arctic Waters. In Yearbook of Polar Law. http://dx.doi.org/10.1163/22116427-91000019

Scovazzi, Tullio (2001). The Baseline of the Territorial Sea: The Practice of Arctic States. En Elferink Oude y Donald Rothwell (Eds.). The Law of the Sea and Polar Maritime Delimitation and Jurisdiction. Londres: Martinus Nijhoff Publishers.

Scovazzi, Tullio y otros (Eds.) (1989). Atlas of the Straight Baselines. Milán: A. Giuffrè.

Fecha de recepción: 7 de marzo de 2016

Fecha de aprobación: 22 de abril de 2016 